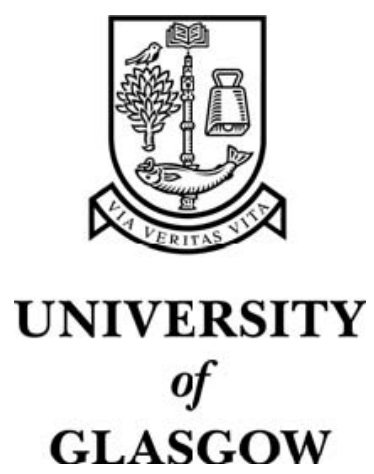

Danbolt, J. (1995) An analysis of gains and losses to shareholders of foreign bidding companies engaged in cross-border acquisitions into the United Kingdom, 1986-1991. European Journal of Finance 1(3):pp. 279309.

http://eprints.gla.ac.uk/3692/ 


\title{
An Analysis of Gains and Losses to Shareholders of Foreign Bidding Companies Engaged in Cross-Border Acquisitions Into the United Kingdom - 1986-1991
}

\author{
Jo Danbolt \\ Department of Accountancy and Finance, \\ Heriot-Watt University, \\ PO Box 807, Riccarton, \\ Edinburgh, EH14 4AT.
}




\title{
An Analysis of Gains and Losses to Shareholders of Foreign Bidding Companies Engaged in Cross-Border Acquisitions Into the United Kingdom - 1986-1991
}

\begin{abstract}
In this paper, the gains and losses to shareholders of 71 foreign companies which made takeover bids for companies listed in the United Kingdom during the 1986-1991 period are analysed.

The average abnormal return during the month of the bid announcement was positive, although not statistically significant. However, both prior to and subsequent to the bid announcement month, the overseas bidders earned highly significant negative abnormal returns. The cumulative abnormal returns over the five month period following the bid announcement were $-4.77 \%$ with the index model and $-9.79 \%$ with the market model.

Further analysis established that Continental European companies performed significantly worse than American bidders. In addition, large companies and companies bidding for large targets, performed significantly better than the other bidders.
\end{abstract}

Keywords: Cross-border, acquisitions, takeovers, bidders. 


\section{INTRODUCTION}

The level of takeover activity in the United Kingdom grew rapidly during the late 1980s. The total value of acquisitions of companies in the UK rose from approximately $£ 2.5$ billion in 1983 to a peak of just under $£ 38$ billion in 1989 . As can be seen from figure 1 , to a large extent this takeover boom was fuelled by cross-border acquisitions into the UK. Indeed, in 1990, takeovers by foreign entities accounted for $58 \%$ of the total value of acquisitions in the UK. It is probable that this increase in cross-border takeover activity was, at least partially, a result of the passing of the Single European Act in 1985.

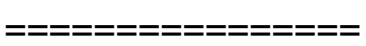

Insert Figure 1 here

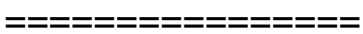

While a substantial amount of research has analysed the wealth effect of domestic mergers and acquisitions, the existing literature on cross-border acquisitions is rather more limited. In addition, as discussed further in section 2, the current literature tends to be heavily skewed towards the US market. The gains or losses to the shareholders of overseas companies from cross-border acquisitions into the UK has largely been left unexplored. The purpose of this study is to fill this gap.

The focus of this paper is on the gains and losses to shareholders of the foreign companies which made takeover bids for listed UK companies during the period from 1986 to 1991. The analysis includes an evaluation of the performance of the cross-border bidding companies prior to and after the bid announcement, as well as during the bid period. In addition to analysing the overall takeover effect, the analysis also attempts to establish whether the abnormal returns are dependent on the nationality of the overseas bidding companies. Crosssectional analysis is also applied to evaluate the significance of certain characteristics on the wealth effects to the shareholders of the bidding companies. The variables included are: (a) whether the bid succeeds or fails, (b) whether or not the offer is competitive or (c) revised, (d) the method of payment, (e) the relative size of the bidding and target companies, and (f) the absolute size of the bidder. 
This paper is organised as follows. Section 2 looks at the theoretical considerations and contains a short overview of the existing literature. The data sources and the methodologies applied in this paper are explained in section 3. The results are discussed in section 4, while a brief summary and the conclusions are given in section 5 .

\section{LITERATURE REVIEW AND THEORETICAL CONSIDERATIONS}

Several studies have analysed the wealth effects to bidding companies of engaging in domestic acquisitions. Focusing on takeovers in the UK, Firth (1979) found that the acquiring companies experienced an abnormal loss of $6 \%$ during the two month period surrounding the bid announcement. In value terms, these losses offset any gains made by the target companies' shareholders. However, a study by Franks and Harris (1989) contradict Firth's findings. Franks and Harris analysed 1,800 UK takeovers during the 1955 to 1985 period. They found that bidding company shareholders gained modestly, or at least did not lose from the bid announcement.

Limmack (1991) analysed takeover bids in the UK announced between 1977 and 1986. Limmack applied three different test models ${ }^{i}$, and for all three models found that bidding companies on average experienced positive abnormal returns in the month prior to the bid announcement. However, while Limmack found bidders to perform well prior to the acquisitions, they tended to lose from the acquisitions. During the period from the bid announcement through to the outcome day, bidders lost, regardless of bid outcome (although the loss was larger in unsuccessful bids). During the 24 months following the announcement of bid outcome, bidders in both completed and abandoned offers experienced "...a downward drift in returns over the whole period". (p. 248).

Jensen and Ruback (1983) summarised the results of 13 US studies. For the bidding companies they found a positive announcement effect in successful offers, although most of this gain was lost over the year following the takeover. Franks, Harris and Titman (1991) found no abnormal returns to bidders in 399 US acquisitions.

As was highlighted by Fatemi and Furtado (1988), cross-border acquisitions may have 
very different characteristics from domestic acquisitions:

"Transnational acquisitions would not be any different from domestic acquisitions, and therefore would not have any differential wealth effects, if

(1) the market for corporate control were not segmented across national boundaries,

(2) the capital markets were not internationally segmented, and

(3) there were no net benefits (disadvantages) associated with international diversification.

However, differential wealth effects may exist if any of these conditions do not hold." (p. 364).

Combining this with the very substantial value of cross-border acquisitions into the UK, it is rather surprising that there appears to be only two previous studies which have analysed the wealth effects of cross-border acquisitions into this market. Conn and Connell (1990) analysed the share price performance of both bidding and target companies in mergers between companies based in the United States and the United Kingdom which took place between 1971 and 1980. With regard to their sample of 35 American companies acquiring in the UK, Conn and Connell found that these corporations performed very well prior to the announcement of the cross-border bids, but over the six months following the bid announcement, the share prices experienced on average an abnormal loss of $2.5 \%{ }^{\mathrm{ii}}$. Conn and Connell concluded that:

"Controlling for methods used, international mergers by US firms are viewed more sceptically by the securities market than are domestic US mergers at the time of first public announcement." (p. 702).

A similar study was carried out by Feils (1993), who in her unpublished Ph.D. thesis analysed target and bidding companies in cross-border acquisitions between the UK and the US, as well as German acquisitions of US firms during the time period 1980 to 1990 . Using the market model for a short event window ( $t-5$ to $t+5$ days, where $t=0$ is the day of the bid announcement), she concluded that "...U.S. and German acquiring firms lose insignificantly, while British acquiring firms lose significantly in international acquisitions". (p. v).

While the papers by Conn and Connell and Feils cast some interesting light on crossborder acquisitions into the UK, their studies are rather restrictive in that they did not include an analysis of takeovers into the UK by companies based outside the US. However, as detailed 
below, most other studies of cross-border acquisitions have tended to be even more restrictive with regard to which, if any, foreign companies to include in the analysis.

Any study based on share price information for overseas companies soon runs into the problem of data limitations. The majority of researchers of cross-border acquisitions have avoided the issue by excluding the foreign companies from the analysis, and have simply restricted the analysis to the companies based in a country such as the United States where data is comparatively easy to obtain. For example, Wansley, Lane and Yang (1983), Shaked, Michel and McClain (1991), Harris and Ravenscraft (1991), Swenson (1993) and Dewenter (1995), all compared the share price performance of US target companies in cross-border and domestic acquisitions. The foreign bidding companies were not included in their analyses.

Similarly, Fatemi and Furtado (1988), Doukas and Travlos (1988), Sudia (1992), Markides and Ittner (1994), and Manzon, Sharp and Travlos (1994), analysed cross-border acquisitions, focusing on the American acquiring companies. Again the foreign companies were ignored. With regard to the American cross-border bidders, Fatemi and Furtado (1988) found weak evidence supporting the view that "...foreign acquisitions are associated with positive abnormal returns when they are the means of an initial entry into a foreign market. No significant wealth effects are present otherwise". (p. 363).

In their analysis of 301 cross-border acquisitions, Doukas and Travlos (1988) reached similar conclusions. On the day of the bid announcement, the bidding companies on average experienced a small, statistically insignificant, positive abnormal return (0.08\%). However, this average masked the fact that "Shareholders of U.S. firms expanding internationally for the first time experience insignificant positive abnormal returns, while shareholders of MNCs [multinational corporations] operating already in the target firm's country experience insignificant negative abnormal returns". (p. 1161).

In their study, Markides and Ittner (1994) concluded: "The two-day abnormal return for our study of 276 U.S. international acquisitions between 1975 and 1988 was .32\%, statistically significant at the 10\% level". (p. 354). Sudia (1992) analysed the effect on US bidders of regulatory changes governing cross-border acquisitions, while Manzon, Sharp and Travlos (1994) looked at the consequences of changing US tax rules for US cross-border bidders. 
Tessema (1985) analysed abnormal returns to US bidding and US target companies in cross-border and domestic acquisitions during the period 1974 to 1983 . For the bidders he found that "...stockholders of acquiring firms at least do not lose". (p. iii). For the total analysis period, Tessema found no differences in abnormal returns in domestic US and cross-border acquisitions.

A few studies have included an analysis of the foreign target and/or bidding companies in cross-border acquisitions. Mathur, Chhachhi and Sundaram (1989) analysed a small sample of 18 cross-border mergers into the US. They found that the overseas bidders lost a statistically insignificant 3\% during the 31 day period surrounding the bid announcement. In their analysis of cross-border bidders into the United States, Servaes and Zenner (1990) studied the 70 overseas bidding companies which had their shares or American Depositary Receipts traded in the United States. They found that these companies had an insignificant negative abnormal return of $0.15 \%$ during a two day event window.

Mathur, Rangan, Chhachhi and Sundaram (1994) analysed the abnormal returns from cross-border acquisitions into the US by 77 overseas bidding companies from 10 countries. They concluded: "The results show that stockholders of foreign bidders earn significant, negative abnormal returns surrounding the announcement of an acquisition in the USA. These abnormal returns become increasingly negative over the 15 days after the announcement of the acquisition, indicating that more information about the acquisition is revealed to investors subsequent to the initial announcement". (p. 107).

Both Kang (1993) and Pettway, Sicherman and Spiess (1993) analysed abnormal returns to US targets and Japanese bidders from cross-border acquisitions into the US. Both studies found significant positive abnormal returns to the Japanese acquiring companies. Song (1993) analysed the gains and losses to US targets and overseas bidding companies from 118 crossborder acquisitions into the US. He found that the overseas bidders lost marginally $(-0.42 \%)$ over a 21 day period from $\mathrm{t}-10$ to $\mathrm{t}+10$ days. However, Song found that larger bidders on average did better than smaller bidders. Thus, "Although abnormal returns are negative, acquisition announcements, on average increase acquirers' stock values by $\$ 30.3$ million". ( $p$. 126). 
In her unpublished Ph.D. thesis, Biswas (1990) studied cross-border acquisitions between financial companies. Her study was truly international, with an analysis of both target and bidding companies from all over the worldiii. The average abnormal return over a 11-day period surrounding the bid announcement ( $t-5, t+5$ days) was $0.003 \%$. Her results are, however, difficult to interpret, as they do not identify returns to bidders or targets from acquisitions into specific countries, but rather combines takeovers into a total of 11 countries.

While the studies by Conn and Connell (1990) and Feils (1993) established that US companies generally under-performed at the announcement of, and subsequent to, an acquisition in the UK, there is a general lack of knowledge as to what impact cross-border acquisitions into the UK have on the share price of the overseas bidding companies. The Conn and Connell paper covered the period from 1971 to 1980. The study by Feils thus appears to be the only previous work looking at takeovers into the UK during the cross-border takeover boom of the late 1980s. It should also be borne in mind that her study analysed abnormal returns over a short time frame (11 days). As is discussed further below, such an event window may not be sufficient to capture the full wealth effect of the cross-border acquisitions. An additional limitation of the existing literature, is that there appears to be no relevant published material on cross-border acquisitions into the UK by companies based outside the US. This study aims to fill this gap.

The existing takeover literature has identified a number of variables which may have an impact on the abnormal returns to bidding companies:

* As was mentioned above, Limmack (1991) found that bidding companies performed significantly worse in failed takeovers than in successful ones. Similar observations have been made in other studies, such as Asquith (1983).

* Bradley, Desai \& Kim (1988) found that competitive bids had a negative impact on the bidding companies abnormal returns. However, Franks, Harris and Titman (1989) argued that "...bidders pay more for targets that are contested (multiple bidders) ... but that bidders do not experience significant negative announcement returns as a consequence". (p. 92). 
* It may also be hypothesised that the bidding company will perform worse when it is forced to revise the initial offer (e.g., due to opposition from target company management or due to the offer being competitive).

* Several studies (e.g., Franks and Harris (1989)) have found that the bidding company performs significantly better in cash than in equity financed takeovers. However, Franks, Harris and Titman (1991) found that "Although the difference between the performance of all-cash and all-equity bidders is large, it is ... not statistically significant". (p. 92). Similar results were obtained by Agrawal, Jaffe and Mandelker (1992).

* The acquisition of a large target is likely to have a greater impact on the fortunes of the acquiring company than a small acquisition. Indeed, previous research such as Asquith, Bruner and Mullins (1983), have found a positive relationship between bidding company cumulative abnormal returns and the size of the target relative to the size of the bidder. Similarly, Markides and Ittner (1994) found the relative size (as measured by value of sales rather than market values) of the bidder and target to be highly significant. However, Franks, Harris and Titman (1991) found "...no significant link between relative size and either target or bidder gains". (p. 93).

* It may be hypothesised that larger companies will have more experience in undertaking acquisitions or operating abroad than smaller companies. In addition, larger companies are likely to have more resources available to be able to fully analyse and plan the crossborder acquisition. Indeed, Song (1993) found that large bidders on average performed better than smaller bidders. However, in their study of US takeovers, Franks, Harris and Titman (1991) found "...smaller firms clearly outperforming larger firms...". (p. 90).

This study will analyse the impact of these bid characteristics on the level of abnormal returns to overseas companies engaged in making cross-border bids for UK listed companies.

\section{DATA SOURCES AND METHODOLOGY}

This paper analyses cross-border takeover bids for UK listed companies that were made on or after January 1st 1986 and for which the outcome (successful or failed) was known prior to 
the end of December 1991. Information as to what takeover bids took place, the name of the bidding and target companies, the bid outcome, whether or not the bid was competitive, and the method of payment, was obtained from Acquisitions Monthly. The nationality of the bidding companies was also generally available from Acquisitions Monthly. When a takeover has been carried out through a subsidiary, the ultimate parent company has been analysed rather than the subsidiary. For the majority of the foreign bidding companies the classification of nationality used by Acquisitions Monthly (which classifies the bidding companies according to where they have their registered office) has been adopted in this paper. However, for a few of the bidding companies, a stock market listing was only available in a market other than that specified by Acquisitions Monthly as the home country of the company. In these circumstances, the share price performance of the bidding company has been compared to the performance of the stock market index in the market in which the company is listed. Similarly, the nationality of the company has been re-classified to be the country in which the shares are listed.

The market capitalisation for the bidding companies was obtained from Datastream. The market value was measured 9 months prior to the date of the bid announcement, and converted into Sterling at the exchange rate operating at that time. The market values for the target companies were obtained from the London Business School Risk Measurement Service (Dimson \& March) ${ }^{\mathrm{iv}}$.

Both Fatemi and Furtado (1988) and Doukas and Travlos (1988) argued that bidding companies perform better when entering into new markets. A similar analysis has not been performed in this study, due to lack of data on the bidding companies previous experience abroad $^{v}$.

During the 6 year period of analysis, a total of 966 takeover bids were made for UK companies listed either on the Stock Exchange or in the OTC market; 756 (78.3\%) by other UK companies or individuals, $208(21.5 \%)$ by foreign entities, and finally 2 bids $(0.2 \%)$ involved foreign and domestic companies bidding together.

The focus of this study is on the 208 cross-border takeover bids. This paper thus provides a census of the cross-border takeover bids into the UK during the 1986-1991 period, as far as data allowed. However, not all these takeover bids were suitable for inclusion in the 
analysis ${ }^{\mathrm{vi}}$, and a total of 34 bids had to be rejected. Consequently, the total number of takeover bids for which analysis was attempted was $174^{\text {vii }}$.

This study has relied on Datastream International for the overseas share price data. While Datastream adjusts share prices for capitalisation changes, it does not make adjustments for dividend payments. Share prices therefore had to be separately adjusted for dividend payments in order to obtain return data. While Datastream's coverage of share price information is generally very good, it is surprisingly patchy with regard to dividend payments. To overcome this problem, it was necessary to obtain a large part of the dividend data from various Stock Exchanges and foreign companies directly.

When trying to establish whether shareholders gain or lose from a takeover, it is not sufficient simply to look at changes in share prices (or return data) directly. As share prices change for a number of reasons unrelated to bid announcements, the return data ought to be analysed in a way which excludes the effect of changes in the level of the stock market as a whole. There are several models which are commonly used for this purpose. In an analysis of domestic UK acquisitions, Limmack (1991) applied three different test models, and concluded that "The results provide conflicting evidence depending on the period included in the analysis of abnormal returns and the control model used". (p. 250). Similarly, Franks and Harris (1989) also obtained different abnormal returns, particularly in the post-bid period, depending on which of their three models was being applied. In this study, two of the more common models have been applied: the market model (MM), and the index model (IM). These models are specified as follows:

$$
\begin{array}{ll}
\text { MM: } & \log _{\mathrm{e}} R_{\mathrm{i}}=\alpha_{\mathrm{i}}+\beta_{\mathrm{i}} \log _{\mathrm{e}} \mathrm{R}_{\mathrm{m}}+\mu_{\mathrm{i}} \\
\mathrm{IM}: & \log _{\mathrm{e}} \mathrm{R}_{\mathrm{i}}=\log _{\mathrm{e}} \mathrm{R}_{\mathrm{m}}+\mu_{\mathrm{i}}
\end{array}
$$

where $\log _{\mathrm{e}}$ is the natural $\log , \mathrm{R}_{\mathrm{i}}$ is the return on the share, $\mathrm{R}_{\mathrm{m}}$ the return on the market ${ }^{\mathrm{viii}}, \alpha_{\mathrm{i}}$ and $\beta_{\mathrm{i}}$ regression coefficients, and $\mu_{\mathrm{i}}$ the error term (the abnormal return during the analysis period). The MM parameters for each bidder have been estimated using OLS regressions on monthly data for a 60 month period ending 9 months prior to the month of the bid announcement ${ }^{\mathrm{ix}}$. 
If the stock market is efficient, share prices should react quickly to the release of new information (see Fama (1991)). However, with regard to takeovers, previous studies have indicated that information appears to leak to the market prior to the official bid announcement ${ }^{\mathrm{x}}$. As argued by Magenheim and Mueller (1988), analysis of takeover effects would be relatively easy "...if all of the relevant information regarding an acquisition were to become public on the day the acquisition is announced and the market could be assumed to adjust fully in that day to the new information. But news of an acquisition is known to leak into the market prior to the first public announcement, and it is unrealistic to assume that the market is capable of predicting the full future consequences of an acquisition immediately upon learning of it". (p. 172). In addition, in order to establish whether the post bid share price performance differ between e.g., successful and failed bidders (as found by e.g., Limmack (1991)), it is necessary to include a period subsequent to the bid announcement in the analysis. Consequently, in this study, the abnormal returns are calculated over a relatively long time period, extending from eight months prior to the month of the bid announcement (t-8), to five months after the month of the bid announcement $(t+5)$. However, this period has been split into three separate sub-periods: the pre-bid period $(t-8, t-2)$, the bid period $(t-1, t=0)$, and the post-bid period $(t+1, t+5)$.

While Datastream is possibly one of the best data sources available for overseas share price information, there is still a problem of data availability. Of the 174 overseas bidding companies, information for $63(36.2 \%)$ was not available from Datastream. This may be due to the companies either not being listed at any stock exchange (e.g., private companies) or, for some reason, not being included in the Datastream database.

An additional problem encountered was insufficient data availability. For 40 companies, while some information was available from Datastream, this was insufficient for any analysis ${ }^{\mathrm{xi}}$. This left a total of 71 overseas bidding companies for which sufficient data was available to apply the IM. As the MM requires more data, the sample size for this model was unfortunately further restricted, to 50. A full breakdown of the population and sample sizes by nationality of the bidding company, is given in table 1.

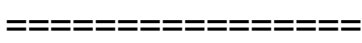

Insert Table 1 here 
Because of data limitations, the nationalities of the bidding companies for which data was available for analysis do not fully represent the nationalities of the population of cross-border takeover bids as a whole. While companies from Austria, Belgium, Bermuda ${ }^{\mathrm{xii}}$, British Virgin Islands, Cayman Islands, Finland, Hong Kong, Liechtenstein, Luxembourg, Malaysia, Panama, South Africa and Saudi Arabia accounted for 28 (13.5\%) of the 208 cross-border takeover bids for UK companies, insufficient data was available for any of these takeover bids to be analysed.

There is a dominance of acquisitions by US companies, both in the population, and even more so in the analysis. While US bidders accounted for $20.7 \%$ of all cross-border takeover bids during the period from 1986 to 1991 , they account for $23.9 \%$ of the IM sample and $32 \%$ of the MM sample. Despite this nationality-bias, companies from a total of 14 overseas countries are included in the analysis. This study therefore gives a fuller picture of the gains or losses from cross-border acquisitions into the UK incurred by shareholders of the overseas bidding companies than did the studies by Conn and Connell (1990) and Feils (1993), who studied mergers between US and UK companies.

There is also a possibility of a size-bias in the Datastream files. However, as the market capitalisation of the non-listed companies is not known, it is impracticable to try to establish whether the market value of the companies included in the analysis is larger (or smaller) than the average market value for all the overseas bidding companies. A size-bias is therefore virtually impossible to either prove or refute. Of the 71 cross-border takeover bids that have been analysed, the average market value of the overseas bidding companies was $£ 2,374.6$ million. There were, however, large variations in the size of the overseas bidding companies, with a few bidding companies with fairly low market values. The distribution of market values of the overseas bidding companies is given in table 2 .

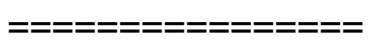

Insert Table 2 here

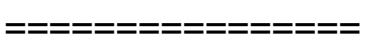

As mentioned previously, several factors may have an impact on the abnormal return to the overseas bidding companies. Cross-sectional analysis was undertaken in an attempt to 
explain the cumulative abnormal returns. The variables applied are defined as follows:

Outcome: A dummy variable taking the value of 0 if the bid was successful (in that the bidding company obtained control over the target company) and 1 if the offer failed.

Competitive: A dummy variable taking the value of 0 if there was a single bidder and the value 1 if more than one company bid for the target (competitive bid).

Revised: $\quad$ A dummy variable taking the value 0 if the offer was not revised and the value 1 if the terms of the offer were revised (price offered increased).

Pay: $\quad$ A dummy variable taking the value of 0 if there was not a full cash alternative and the value 1 if the offer included a full cash alternative.

Rel Size: The pre-bid market value of the target divided by the pre-bid market value of the bidder.

Size: $\quad$ The natural log of the pre-bid market value of the bidding company.

The analysis obtained are summarised and analysed in the following section.

\section{ANALYSIS OF RESULTS}

\subsection{All Companies}

The signs of the cumulative abnormal returns are given in table 3. As can be seen from this table, approximately $60 \%$ of the overseas bidding companies experienced an abnormal loss over the total analysis period. Indeed, regardless of which model is being applied, approximately half (or more) of the companies had negative abnormal share returns over the period prior to the bid, during the bid period, and during the five month period following the bid announcement.

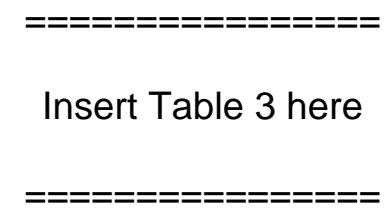

The results are similar once the size of the abnormal returns are taken into account. The equally weighted abnormal returns and cumulative abnormal returns are given in table 4 and 
depicted in figure 2.

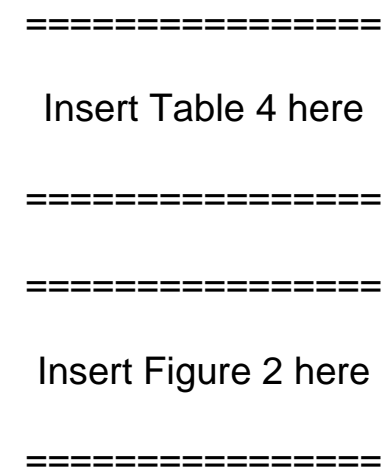

Index Model versus Market Model

As can be seen from table 4, the index model and the market model generally gives consistent results with regard to the direction of any abnormal return. However, as was found by Franks and Harris (1989), the level of the abnormal returns is rather different for the two models ${ }^{\text {iii }}$. This is caused by the different assumptions underlying these models. The index model assumes that all shares have the same characteristics as the market as a whole. Thus $\alpha$ is assumed to be 0 and $\beta$ to be 1 for all companies. For the market model, the parameters are estimated, in this study over a 5 year period ending 9 month prior to the month of the bid announcement. As is indicated in Table 5, the average market model $\alpha$ is above 0 and $\beta$ below 1. These findings are similar to those of e.g., Franks and Harris (1989), Limmack (1991) and Connell and Conn (1993), although Connell and Conn obtained a $\beta$ value for UK bidders above 1.

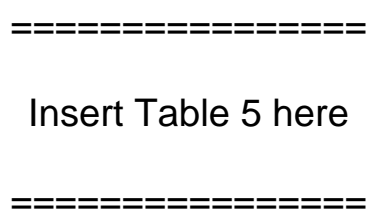

The assumption of the market model is that the historical relationship between the return on the market and the return on the share is a good predictor for the future relationship. One implication of this is that if the share outperformed the market during the parameter estimation period (as reflected in a positive $\alpha$ value), the share is expected to continue to outperform the market during the event period.

In this study, the mean $\alpha$ was 0.00923 . One interpretation of this value, is that the 
average bidding company is expected to have a rate of return of $0.9 \%$ per month (or $11.07 \%$ per year) in addition to the rate of return required to compensate for the share's level of systematic risk. The large negative abnormal returns observed using the market model indicates that the overseas bidding companies were not able to fulfil this expectation over the period following the bid announcement. Indeed, as indicated by the index model, the share prices of the overseas bidding companies performed worse than the stock market indices in their home markets around the period of the cross-border bids for UK listed companies.

Connell and Conn (1993) found that the cumulative abnormal returns were highly sensitive to the period over which the market model parameters were estimated: "The sensitivity of CAR estimates to the different estimation periods appear to result from a significant decline in the intercept term, alpha, of the market model from a positive to a negative value from pre to post-event estimation" (p. 63). It may be that companies decide to acquire other companies following a period of unusually good performance. If the market model parameters are estimated during such an exceptional time period, it is possible that the $\alpha$ will be inflated. This study tried to overcome this potential problem by estimating the market model parameters over a long time period, 60 months, ending 9 months prior to the bid announcement. However, the large positive mean $\alpha$ may indicate that even this long time period was insufficient to overcome the problem of a positive mean $\alpha$ value being caused by exceptionally good pre-bid share performances of the overseas bidding companies.

Another interpretation of the high $\alpha$ values (and low $\beta$ values) observed in this study is that these results are caused by "thin" or nonynchronous trading. If a share is infrequently traded, the market model may be misspecified. "The major source of bias is the tendency for prices recorded at the end of a time period to represent the outcome of a transaction which occurred earlier in or prior to the period in question". (Dimson (1979), p. 179). As was explained by Fowler, Rorke and Jog (1980), $\beta$ will be downwardly biased if the share is less frequently traded than the index, and upwardly biased if the index is less frequently traded than the share.

The low $\beta$ values in this study could thus have been caused by the shares of the overseas bidding companies being less frequently traded than the stock market indices in the relevant markets. It should be remembered, however, that infrequent trading may be 
predominately a feature of small companies (see Roll (1981)). While some of the bidding companies included in this study are small, the majority of bidders are fairly large companies. Thin trading is generally more of a concern in studies analysing target companies, as these are generally significantly smaller than the bidding companies. In addition, nonsynchronous trading is also more likely to cause statistical difficulties in studies based on daily rather than monthly data (Brown and Warner (1985)).

Various methods have been suggested for correcting the beta values for thin trading. Fowler, Rorke and Jog (1980) evaluated the effectiveness of four such techniques ${ }^{\text {xiv }}$, and concluded: "In general, the OLS beta estimates seem to be better than those produced using any of the bias correcting techniques". (p. 89). Fairly similar conclusions were reached by Brown and Warner (1985), who argued that "Methodologies based on procedures suggested by Scholes and Williams and of Dimson do seem to reduce biases in OLS estimates of $\beta$. However, the specification and power of the actual tests for abnormal performance is similar to that obtained with the OLS market model, and this conclusion applies to samples having trading frequencies systematically different from average". (p. 26). Consequently, no adjustments have been made to the market model $\beta$ in this paper.

As indicated above, the assumptions underlying the models cause the abnormal returns to differ between the market model and the index model. In this study the results of both models will be reported for comparison purposes ${ }^{\mathrm{xv}}$.

Pre-bid period $(t-8, t-2)$

As can be seen from table 4 , the overseas bidding companies on average experienced a significantly positive abnormal return during the month t-6. It is not yet known why such positive abnormal returns were observed. However, over the following five months, the average abnormal returns were negative, and the cumulative abnormal returns over the pre-bid period were negative; $-1.00 \%$ with the index model, and $-5.63 \%$ with the market model. The negative CAR was significant at the $10 \%$ level for the MM. Thus, over the pre-bid period, the bidding companies marginally underperformed the market, but performed significantly worse than in previous periods. 
Bid period $(t-1, t=0)$

There were on average small abnormal gains during the month of the bid announcement. These gains, of $0.80 \%$ for the index model and $0.23 \%$ for the market model, were not statistically significant. However, abnormal losses were encountered during the month prior to the bid announcement, counterbalancing the gains observed in the bid month. Indeed, for both test models, the bid announcement month was the only month between $t-5$ and $t+5$ for which the average abnormal returns were positive.

Thus, looking simply at the short term abnormal returns, the small positive abnormal return in the bid announcement month observed in this study, is somewhat inconsistent with the results of Feils (1993), who established that US bidders lost marginally over an 11 day period surrounding the announcement of a takeover bid for a UK based company. The findings in this study may, however, be consistent with those of Tessema (1985), Doukas and Travlos (1988), and Markides and Ittner (1994), who all applied short event windows to establish that US companies gained, or did at least not lose, from cross-border acquisitions. It should be remembered, however, that the UK was only one of the target countries included in these studies. With regard to studies analysing cross-border acquisitions into the United States, several papers have established (insignificant) short-term abnormal losses to the cross-border bidders (Mathur, Chhachhi, and Sundaram (1989), Servaes and Zenner (1990), and Song (1993)). It should be remembered, however, that the positive $t=0$ abnormal returns observed in this study are not statistically significant and, as discussed further below, the bidding companies, on average, experienced significant negative abnormal returns over the period following the bid announcement. 
Post-bid period $(t+1, t+5)$

On average, the overseas bidding companies encountered a negative abnormal return in every month following the bid announcement. The post-event cumulative abnormal returns were $-4.77 \%$ with the index model (significant at $10 \%$ ), and $-9.79 \%$ with the market model (significant at the $1 \%$ level). Thus, as was the case in the study by Conn and Connell (1990), overseas bidding companies, on average, experienced abnormal losses over the period following the bid announcement. However, the level of the cumulative abnormal returns are much higher than those obtained by Conn and Connell. It thus appears that cross-border bidders into the UK over the 1986 to 1991 period performed worse than did US companies acquiring in the UK over the 1971-1980 period.

In this study, the average abnormal returns were negative in every month following the bid announcement. Similar negative post-announcement drifts were found by e.g., Asquith (1983), Franks, Harris and Mayer (1988), and Agrawal, Jaffe and Mandelker (1992). As outlined by Fama (1991), there is an ongoing debate with regard to what may explain this drift. There are at least three possible explanations.

Firstly, it may be the case that price sensitive information is released to the market after the official bid announcement. For example, the eventual outcome of the bid will not be known until some time after the offer has been made. As argued by Roll (1986), "At the original bid announcement ... there is only a probability of success. Between the bid announcement and the final outcome this probability goes to 1.0 for the bids in the successful group. Thus, if the combination itself has value for the bidder, these bidding firms should increase in value over this interim period. They do not". (p. 209).

The proposition that the negative drift is attributable to the failed bidders is not supported by the data in this study. Firstly, while the average time to completion (in the successful bids) was approximately 31 days (standard deviation of 29 days), the largest negative postannouncement abnormal return was observed during $t+5$. It is not yet known why such large abnormal returns were encountered during this time period. A further problem with the information release hypothesis, is that while bidding companies in failed takeover bids performed marginally worse than successful bidders, the negative abnormal returns over the post-bid 
period observed in this study are not restricted to bidders in failed acquisition attempts or to any other clearly identifiable group of bidders. All groups of bidders, on average, appears to have made abnormal losses during this time period.

The negative post-announcement abnormal returns to bidders may also have been due to the bidding companies overpaying for their targets, but the market being slow to realise this overpayment. This would be consistent with the "hubris" hypothesis suggested by Roll (1986). "One possibility is that acquiring firms on average pay too much for their target firms, but the market only realizes this slowly; the market is inefficient" (Fama (1991), p. 1602). However, Agrawal, Jaffe and Mandelker (1992) did not find support for the hypothesis that the postannouncement drift was caused by the market being slow to adjust the share price following the merger announcement.

A third possible explanation for the post-announcement drift is that it is caused by model misspecification. Both the market model and the index model assume $\beta$ to remain constant over time. The models do therefore not allow for any changes in risk. If the level of systematic risk of the bidder changes over the time period of the bid, this may render the models inappropriate. Franks, Harris and Titman (1991) investigated this point, and argued that "...our results indicate that prior findings of negative postmerger share-price performance for bidders are more likely due to benchmark errors than to mispricing at the time of the announcement". (p. 95).

Some researchers have, however, gathered evidence rejecting the theory that postannouncement drift is caused by inadequate measurement of risk changes. Agrawal, Jaffe and Mandelker (1992) analysed the post-merger performance of US acquiring firms (1955-1987), and "...conclude that Franks, Harris and Titman's results are specific to their sample period". (p. 1614). Agrawal, Jaffe and Mandelker found that "...neither the firm size effect nor beta estimation problems are the cause of the negative post-merger returns". (p. 1605). In their study of earnings announcements, Ball, Kothari and Watts (1993) argued that "The results suggest that post-announcement drift persists after controlling for risk changes, but it is weaker than reported previously [when risk was assumed to be constant]". (p. 632). Similarly, Bernard and Thomas (1989), "...concluded that much of our evidence cannot plausibly be reconciled with arguments built on risk mismeasurement but is consistent with a delayed price response". (p. 
34). Thus, the explanation of the post-announcement drift still eludes us.

In the current study, statistically significant negative abnormal returns were observed for the post announcement period with both the market model and the index model. Insufficient post-announcement return data was available to test for a significant change in the level of systematic risk of the overseas bidders. It is therefore not known whether the negative postannouncement abnormal returns are attributable to information release, market inefficiency or model misspecification. This is an area which would benefit from further research.

\subsection{National Variations}

As indicated in table 1, a total of 14 different nationalities were represented in the sample of 71 overseas bidding companies analysed in this study. Consequently, there was insufficient data available in order to test the significance of the different levels of abnormal returns to bidding companies from each of the countries represented.

As indicated in the literature review, while the available evidence is mixed, there is some support for the notion that bidding companies based in the US do at least not perform worse than bidding companies based in the UK. With regard to cross-border acquisitions, Conn and Connell (1990) found that while US companies acquiring UK companies lost from these transactions, UK companies acquiring in the US encountered even larger negative abnormal returns.

It may be the case that, when acquiring abroad, the performance of the bidding company is dependent upon their previous takeover experience, and in particular the experience in crossborder acquisitions. It may further be hypothesised that companies from economies with large scale domestic and cross-border takeover markets are more likely to have such experience than are companies based in economies where the takeover market is less vigorous. (As mentioned previously, insufficient information was available to ascertain the actual degree of takeover experience of the overseas companies).

As the level of takeover activity in general, and in particular the number of cross-border transactions is commonly lower in Continental Europe than it is in the UK or the US, then one would expect the abnormal returns to companies based in Europe (excluding the UK) to be 
inferior to the performance of American bidders if the above hypotheses are true.

In order to test these hypotheses, the sample was split into European versus American bidders. America includes the US and Canada; both countries where both domestic and crossborder takeovers are prevalent (see e.g., OECD (1984) and Gray and McDermott (1988)). As can be seen from the results in table 6 , over the total analysis period from $t-8$ to $t+5$, American bidders performed (with the index model significantly) better than European bidders. While the cumulative abnormal returns are negative for both groups of companies, they are significantly below zero only for European bidders. The findings for takeover bids for UK listed companies are thus consistent with the hypothesis that bidding companies from markets with large numbers of cross-border takeovers perform better than other cross-border bidders, although there may possibly be other explanations for the difference in performance of American and European bidders.

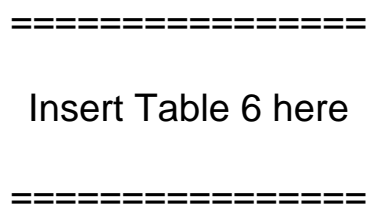

\subsection{Cross-Sectional Analysis}

Cross-sectional analysis was undertaken in order to establish the significance of various bid characteristics on the share price performance of the overseas bidding companies. The analysis was based on the cumulative abnormal returns for the pre-bid period (t-8, t-2), the bid period $(t-1, t=0)$, the post-bid period $(t+1, t+5)$, as well as the total analysis period $(t-8, t+5)$.

The explanatory powers of the regressions varies depending on which time period is being analysed. However, the adjusted $R^{2}$ values are generally fairly high. As indicated in table 7, for the pre-bid period, up to $12.6 \%$ of the cross-sectional variability can be explained (significant only at the $11 \%$ level).

As reported in table 8 , the maximum $\mathrm{R}^{2}$ for the bid period was a more modest $7.1 \%$, although significant at the $10 \%$ level. Corresponding figures for the post-bid period were $8.2 \%$ (significant only at the $12 \%$ level) (not reported), and for the total analysis period (table 9) a highly respectable $16.7 \%$ (significant at the $2 \%$ level). These values compares well to most 
previous studies of abnormal returns to bidders in cross-border acquisitions. For example, although highly statistically significant, the analysis by Doukas and Travlos (1988) explained only $3.5 \%$ of the cross-sectional variability in cumulative abnormal returns for the whole sample, and a maximum of $8.13 \%$ for a subsample of bidders. Mathur, Rangan, Chhachhi and Sundaram (1994) obtained a highly significant $R^{2}$ of $11.77 \%$. Markides and Ittner (1994) obtained a $R^{2}$ of $16.5 \%$ for the full sample, and a very impressive $42.3 \%$ for a small subsample.

The following sections discusses the importance of the seven different explanatory variables included in the cross-sectional regressions in this study.

\section{Successful versus Failed Bids}

Of the 71 takeover bids analysed using the index model, 12 (17\%) failed. The corresponding figures for MM were 10 failed bids from 50 , giving a failure rate of $20 \%$.

As one would expect, there was no significant difference in the performance of successful and unsuccessful bidders during the period preceding the bid. During the bid announcement period, the abnormal returns were again very similar, indicating that the market had, on average, not anticipated the eventual failure of the bid by the end of the bid announcement month.

As observed in previous studies, unsuccessful bidders performed worse than successful bidders over the period following the bid announcement. The difference in CAR was generally not, however, statistically significant. 


\section{Competitive versus Uncompetitive Bids}

A total of $14(20 \%)$ of the index model, and $13(26 \%)$ of the market model bids were competitive. Overseas companies who's subsequent cross-border bids turned out to be competitive, performed significantly worse than the other bidding companies over the period prior to the bid. One possible explanation for this finding, is that it was caused by the forthcoming bid. This could be the case if the market was not only able to predict the forthcoming bid, but also that the bid would be competitive. A more plausible explanation, however, is that weak companies, as reflected in a poor pre-bid share performance, are more likely to attract rival bidders than are well performing bidders. Thus, the poor pre-bid performance may explain why the bid was competitive rather than vice versa.

No significant differences in abnormal returns between single and competitive bidders was observed during the bid period. Over the period following the bid announcement, competitive bidders performed significantly worse than the bidders engaged in uncompetitive bids (significant at the $10 \%$ level for both test models). For the total analysis period from t- 8 to $t+5$, bidders in competitive bids encountered significantly larger negative cumulative abnormal returns than did the successful bidders.

\section{Revised versus Unrevised Bids}

None of the regressions produces significant coefficients for the effect of the bid being revised. This may be due to the small number of observations; only $8(11 \%)$ of the bids analysed using the IM and $7(14 \%)$ of the MM bids were revised. The results indicates that revised bids do not result in an additional over-payment by the overseas bidder. Indeed, rather surprisingly, the regressions indicate that bidders who increased the offer priced performed, on average, marginally better than other overseas bidding companies. The coefficients for "Revised" were, however, never statistically significant.

\section{Cash versus Equity Offers}

The analysis of the impact of the method of payment proved to be inconclusive due to the small number of transactions where the bidder did not offer a full cash alternative. As most investors are reluctant to accept payment in shares only listed abroad, the vast majority of 
acquisitions tend to be cash financed. Indeed, only 3 (4\%) of the IM and 2 (4\%) of the MM bids did not offer cash. Thus, although the coefficients for "Equity" have the expected positive sign, they are not statistically significant. Similar inconclusive results were reached by Markides and Ittner (1994) who in their study of US cross-border bidders, found that "...contrary to the evidence from domestic acquisitions, the form of payment ... is consistently insignificant". (p. 360).

\section{Size Effects}

Two different size effects were analysed; firstly, the market capitalisation of the target company in relation to the market value of the bidding company, and secondly, the natural log of the market capitalisation of the bidding company. It is interesting to note that the relative size variable is never statistically significant when analysed in isolation. However, when the two different size effects are analysed together, both the variables are generally highly significant.

Over the pre-bid period, overseas companies who subsequently went on to bid for large UK listed companies, performed significantly better (at the $5 \%$ or $10 \%$ level, depending on model specification) than the companies bidding for smaller targets. These results are consistent with the hypothesis that the stock markets were able to predict the forthcoming takeover bids, and although investors on average reacted negatively to the cross-border takeover bids, they responded less severely against companies acquiring large UK companies. Further research would be required in order to test this hypothesis. More significantly (at least with the index model), large companies outperformed smaller bidders over the period prior to the bid announcement.

Over the bid announcement period, the relative size of the bid had some impact on the cumulative abnormal returns of the bidders. The variable was significant at the $5 \%$ level with the MM, but not significant with the IM. Large bidders, irrespective of the bid size, also performed marginally better than smaller bidders over the bid period, although not statistically significant.

Over the period following the bid, the relative size of the target and bidding companies did not help to explain the cross-sectional variation in the level of CAR for the overseas bidding companies. However, large bidding companies continued to outperform the smaller bidders 
after the takeover, with the "Size" variable being significant at the $10 \%$ level with both models (not reported in tables).

Looking at the total analysis period from $t-8$ to $t+5$ (table 9), it is clear that both of the size-related variables are highly significant explanatory variables of the variation in the level of cumulative abnormal returns to the overseas companies bidding for UK listed companies during the 1986-1991 period. Larger bidders performed significantly better than smaller companies. In addition, although the general reaction of the stock market to a cross-border takeover bid was negative (as indicated by the highly significant negative CARs), the market reacted less negatively if the overseas company targeted a large UK company than when they acquired a small firm.

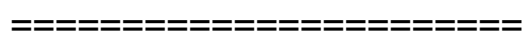

Insert Tables 7, 8, and 9 here

\section{SUMMARY AND CONCLUSIONS}

This paper analyses the abnormal returns to 71 overseas companies, which made takeover bids for listed UK companies during the 1986-1991 period. The analysis revealed small, but statistically insignificant, positive average abnormal returns of $0.80 \%$ with the index model (IM) and $0.23 \%$ with the market model (MM) during the month of the bid announcement. These results are not materially different from those of Feils (1993), who established that US bidders lost insignificantly over an 11 day period surrounding the announcement of an acquisition into the UK during the 1980-1990 period.

However, this study also reveals that the overseas bidding companies, on average, encountered negative abnormal returns in each of the five months following the bid announcement. The post-announcement cumulative abnormal returns (CARs) amounted to a highly significant $-4.77 \%$ for the IM and $-9.79 \%$ for the $\mathrm{MM}$, and the CAR for the total analysis period, stretching from eight months prior to, to five months after the month of the bid announcement, amounted to $-5.34 \%$ with the index model, and $-16.46 \%$ with the market model, both values statistically significant. 
These results are thus fairly consistent with those obtained by Conn and Connell (1990), who established that US companies acquiring in the UK on average lost approximately $2.5 \%$ over the six months following the bid announcement. However, the magnitude of the negative CARs reported in this study are somewhat higher than those observed by Conn and Connell.

These results highlight the importance of the length of the event window, and helps explain why the existing literature on both domestic and cross-border acquisitions tend to produce more favourable results for the bidding companies when analysing abnormal returns over a short time period than is the case with studies analysing medium to long-term effects of mergers and acquisitions. It is not yet known why the overseas bidding companies, on average, encountered negative abnormal returns over the eight month period prior to the bid announcement. In addition, the continued large abnormal losses over the months following the bid announcement also remain a puzzle. These are areas which would benefit from further research.

It was hypothesised that bidding companies from active takeover markets would have more takeover experience and as a result perform better than other bidders engaged in crossborder acquisitions. Analysis revealed that American bidders performed better than bidders based in Continental Europe, thus lending some support to this hypothesis. These results help explain at least part of the difference in the magnitude of the abnormal losses observed by Conn and Connell (1990) for US companies acquiring in the UK, and the results reported in this study, involving bidders from a total of 14 different countries. While both Fatemi and Furtdao (1988) and Doukas and Travlos (1988) controlled for whether or not the bidding companies already had overseas operations, an interesting area for future research would be to establish whether previous takeover (and in particular cross-border) experience has a significant impact on the performance of the bidder around the period of the announcement of a cross-border acquisition.

Cross-sectional analysis revealed that the overseas bidding companies performed better in successful than in failed bids, and in single bidder rather than competitive bids. The size of the target relative to the bidder, as well as the absolute size of the bidder were also found to have significant positive impact on the abnormal returns to the bidding company. Whether or not the bid was revised, or financed by either cash or equity, was not found to have a significant 
impact on the bidding company's fortunes. This may, at least in part have been due to the small number of bids being revised or not involving cash.

I would like to express my deepest gratitude to lan Hirst for his considerable help. Thanks are also due to Pauline Weetman, Ian Thomson, the editor Eve Hicks, as well as two anonymous referees for constructive comments. The responsibility for any remaining errors rests fully with the author. I would also like to thank the numerous companies and stock exchanges who kindly supplied me with the required information. Financial support from Heriot-Watt University, Peder Smedvigs Stipendiefond, and Det Stavangerske Dampskibsselskabs Stipendiefond was grately appreciated. 


\section{DATA SOURCES}

Acquisitions Monthly (1986-1991) Tables on Acquisitions of UK Listed Companies, Tudor House Publications Limited.

Business Briefing (1991a) British Chamber of Commerce, August 16, 12.

Business Briefing (1991b) British Chamber of Commerce, September 27, 15.

Business Briefing (1992a) British Chamber of Commerce, June 26, 14.

Business Briefing (1992b) British Chamber of Commerce, August 21, 12-13.

Business Briefing (1994a) British Chamber of Commerce, February 18, 14.

Business Briefing (1994b) British Chamber of Commerce, March 25, 14.

Datastream International On-line Financial Data Service.

Dimson E \& Marsh P (1985-1991) Risk Measurement Service, 7-13, London Business School, Institute of Finance and Accounting.

\section{REFERENCES}

Agrawal A, Jaffe J \& Mandelker G (1992) The Post-Merger Performance of Acquiring Firms: A Re-examination of an Anomaly, Journal of Finance, XLVII, 1605-1621.

Asquith P (1983) Merger Bids, Uncertainty, and Stockholder Returns, Journal of Financial Economics, 11, 51-83.

Asquith P, Bruner R \& Mullins D (1983) The Gains to Bidding Firms from Merger, Journal of Financial Economics, 11, 121-139.

Ball R, Kothari S \& Watts R (1993) Economic Determinants of the Relation Between Earnings Changes and Stock Returns, The Accounting Review, 68, 622-638.

Bernard V \& Thomas J (1989) Post-Earnings Announcement Drift: Delayed Price response or Risk Premium?, Journal of Accounting Research, 17, Supplement, 1-36.

Biswas R (1990) International Mergers and Acquisitions of Financial Firms, Ph.D. Thesis, Texas A\&M University.

Bradley M, Desai A \& Kim E (1988) Synergistic gains from Corporate Acquisitions and their Division Between Stockholders of Target and Acquiring Firms, Journal of Financial Economics, 21, 3-40.

Brown S \& Warner J (1985), Using Daily Stock Returns - The Case of Event Studies, Journal of Financial Economics, 14, 3-31.

Bühner R (1991) The Success of Mergers in Germany, International Journal of Industrial Organization, 9, 513-532.

Conn R \& Connell F (1990) International Mergers: Returns to U.S. and British Firms, Journal of Business Finance \& Accounting, 17, 689-711. 
Connell F \& Conn R (1993), A Preliminary Analysis of Shifts in Market Model Regression Parameters in International Mergers Between US and British Firms: 1970-1980, Managerial Finance, 19, 47-77.

Cooke T (1988) International Mergers and Acquisitions, Basil Blackwell, 1-82 and 378-414.

Department of Trade and Industry (DTI) (1991) Competition Policy - How it Works, HMSO.

Dewenter K (1995) Does the Market React Differently to Domestic and Foreign Takeover Announcements? Evidence from the U.S. Chemical and Retail Industries, Journal of Financial Economics, 37, 421-441.

Dimson E (1979), Risk Measurement When Shares are Subject to Infrequent Trading, Journal of Financial Economics, 7, 197-226.

Doukas J \& Travlos N (1988) The Effect of Corporate Multinationalism on Shareholders' Wealth:

Evidence from International Acquisitions, Journal of Finance, XLIII, 1161-1175.

Fama E (1991) Efficient Capital Markets: II, Journal of Finance, XLVI, 1575-1617.

Fatemi A \& Furtado E (1988) An Empirical Investigation of the Wealth Effects of Foreign Acquisitions, in Khoury S \& Grosh A Recent Developments in International banking and Finance, Vol. 2, Lexington Books, 363-379.

Feils D (1993) Shareholder Wealth Effects of International Mergers and Acquisitions: Evidence from the United States, the United Kingdom, and Germany, PhD Thesis, University of South Carolina.

Firth M (1979) The Profitability of Takeovers and Mergers, The Economic Journal, 89, 316-328.

Fowler D, Rorke C \& Jog V (1980), Thin Trading and Beta Estimation Problems on the Toronto Stock Exchange", Journal of Business Administration, Vol. 12, No. 1, pp. 77-90.

Franks J, Broyles J \& Hecht M (1977) An Industry Study of the Profitability of Mergers in the United Kingdom, Journal of Finance, XXXII, 1513-1525.

Franks J \& Harris R (1989) Shareholder Wealth Effects of Corporate Takeovers - The UK Experience 1955-1985, Journal of Financial Economics, 23, 225-249.

Franks J, Harris R \& Mayer C (1988) Means of Payment in Takeovers: Results for the United Kingdom and the United States, in Auerbach A Corporate takeovers: Causes \& Consequences, University of Chicago Press, Chicago, 221-263.

Franks J, Harris R \& Titman S (1991) The Postmerger Share-Price Performance of Acquiring Firms, Journal of Financial Economics, 29, 81-96.

Gray S \& McDermott M (1988) International Mergers and Takeovers: A Review of Trends and Recent Developments, European Management Journal, 6, 26-43.

Hannigan B (1988) Insider Dealing, Kluwer Law Publishers.

Harris R \& Ravenscraft D (1991) The Role of Acquisitions in Foreign Direct Investment: Evidence from the U.S. Stock Market, Journal of Finance, XLVI, 825-844.

Jensen M \& Ruback R (1983) The Market for Corporate Control - The Scientific Evidence, Journal of Financial Economics, 11, 5-50. 
Kang J (1993) The International Market for Corporate Control - Mergers and Acquisitions of U.S. Firms by Japanese Firms, Journal of Financial Economics, 34, 345-371.

Kumar R, Sen N \& Shome D (1992) The Agency Cost of Free Cash Flow: Evidence from the Announcement of Acquisition Programs, Working Paper, Virginia Polytechnic Institute and State University, Department of Finance.

Limmack R (1991) Corporate Mergers and Shareholder Wealth Effects: 1977-1986, Accounting and Business Research, 21, 239-251.

Magenheim E \& Mueller D (1988), Are Acquiring-Firm Shareholders Better Off After an Acquisition?, in Coffee J, Lowenstein L \& Rose-Aacerman S, Knights, Raiders, and Targets - The Impact of Hostile Takeovers, Oxford University Press, 171-193.

Manzon G, Sharp D \& Travlos N (1994) An Empirical Study of the Consequences of U.S. Tax Rules for International Acquisitions by U.S. Firms, Journal of Finance, XLIX, 1893-1904.

Markides C \& Ittner C (1994) Shareholder Benefits from Corporate International Diversification: Evidence from U.S. International Acquisitions, Journal of International Business Studies, 343-366.

Mathur I, Chhachhi I \& Sundaram S (1989) Shareholder Returns for International Mergers in the U.S., Managerial Finance (UK), 15, 23-28.

Mathur I, Rangan N, Chhachhi I \& Sundaram S (1994) International Acquisitions in the United States: Evidence from Returns to Foreign Bidders, Managerial and Decision Economics, 15, 107-118.

Organisation for Economic Co-Operation and Development (OECD) (1984) Merger Policies and Recent Trends in Mergers, Paris.

Panel on Takeovers and Mergers (1990) The City Code on Takeovers and Mergers and The Rules Governing Substantial Acquisitions of Shares.

Patell J (1976) Corporate Forecasts of Earnings Per Share and Stock Price Behavior: Empirical Tests, Journal of Accounting Research, 14, 246-276.

Pettway R, Sicherman N \& Spiess D (1993) Japanese Foreign Direct Investment: Wealth Effects From Purchases and Sales of U.S. Assets, Financial Management, 22, 82-95.

Roll R (1977) A Critique of the Asset Pricing Theory's Tests - Part I: On Past and Potential Testability of the Theory, Journal of Financial Economics, 4, 129-176.

Roll R (1981) A Possible Explanation of the Small Firm Effect, Journal of Finance, XXXVI, 879888.

Roll R (1986), The Hubris Hypothesis of Corporate Takeovers, Journal of Business, 59, 197216.

Schipper K \& Thompson R (1983) Evidence on the Capitalized Value of Merger Activity for Acquiring Firms, Journal of Financial Economics, 11, 85-119.

Scholes M and Williams J (1977) Estimating Betas from Nonsynchronous Data, Journal of Financial Economics, 5, 309-327. 
Servaes H \& Zenner M (1990) The Returns to Foreign Acquisitions in the United States, Centre for Research in Security Prices, Working Paper No. 302, University of Chicago, November.

Shaked I, Michel A \& McClain D (1991) The Foreign Acquirer Bonanza: Myth or Reality?, Journal of Business Finance \& Accounting, 18, 431-447.

Siegel S \& Castellan N (1988) Nonparametric Statistics for the Behavioral Sciences, Second Edition, McGraw-Hill, Singapore.

Song K (1993) Value Creation in Cross-Border Acquisitions, Ph.D. Thesis, University of Houston.

Strong N (1992) Modelling Abnormal Returns: A Review Article, Journal of Business Finance \& Accounting, 19, 533-550.

Sudia J (1992) Valuation Effects of Takeover Regulation on Multinational Bidders, D.B.A. Thesis, University of Colorado at Boulder.

Swenson D (1993) Foreign Mergers and Acquisitions in the United States in Froot K Foreign Direct Investment, University of Chicago Press, Chicago and London, 255-281.

Tessema A (1985) Effect of International Mergers and Acquisitions on Shareholder Returns of Participating U.S. Firms, PhD Thesis, University of lowa.

Wansley J, Lane W \& Yang H (1983) Shareholder Returns to USA Acquired Firms and Domestic Acquisitions, Journal of Business Finance \& Accounting, 10, 647-656. 
Figure 1

\section{Total Value of Mergers and Acquisitions in the United Kingdom - Domestic and Cross-Border}

Expenditure on initial payments for acquisitions and mergers by industrial and commercial companies within the UK compared to value of cross-border acquisitions and mergers in the UK by overseas companies. The values include payment in complete acquisitions for both private and public UK companies. The values have not been adjusted for inflation.

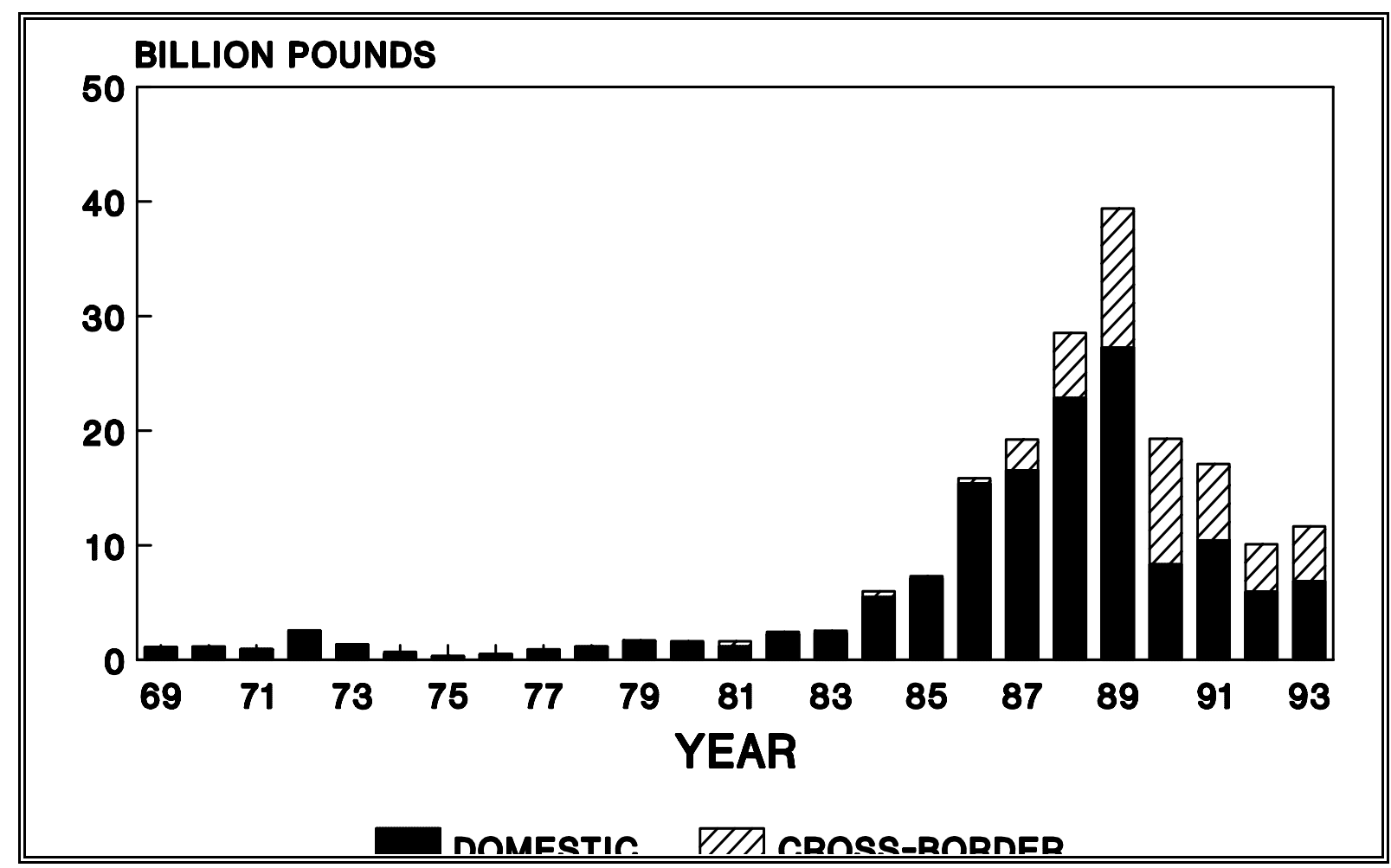

Source: Cooke (1988), and Business Briefing (1991a-1994b). 
Figure 2

\section{Average Cumulative Abnormal Returns to Cross-Border Bidding Companies}

Average cumulative abnormal returns (CAR) to overseas companies making takeover bids for UK listed companies (19861991). For information on model specifications, see table 4.

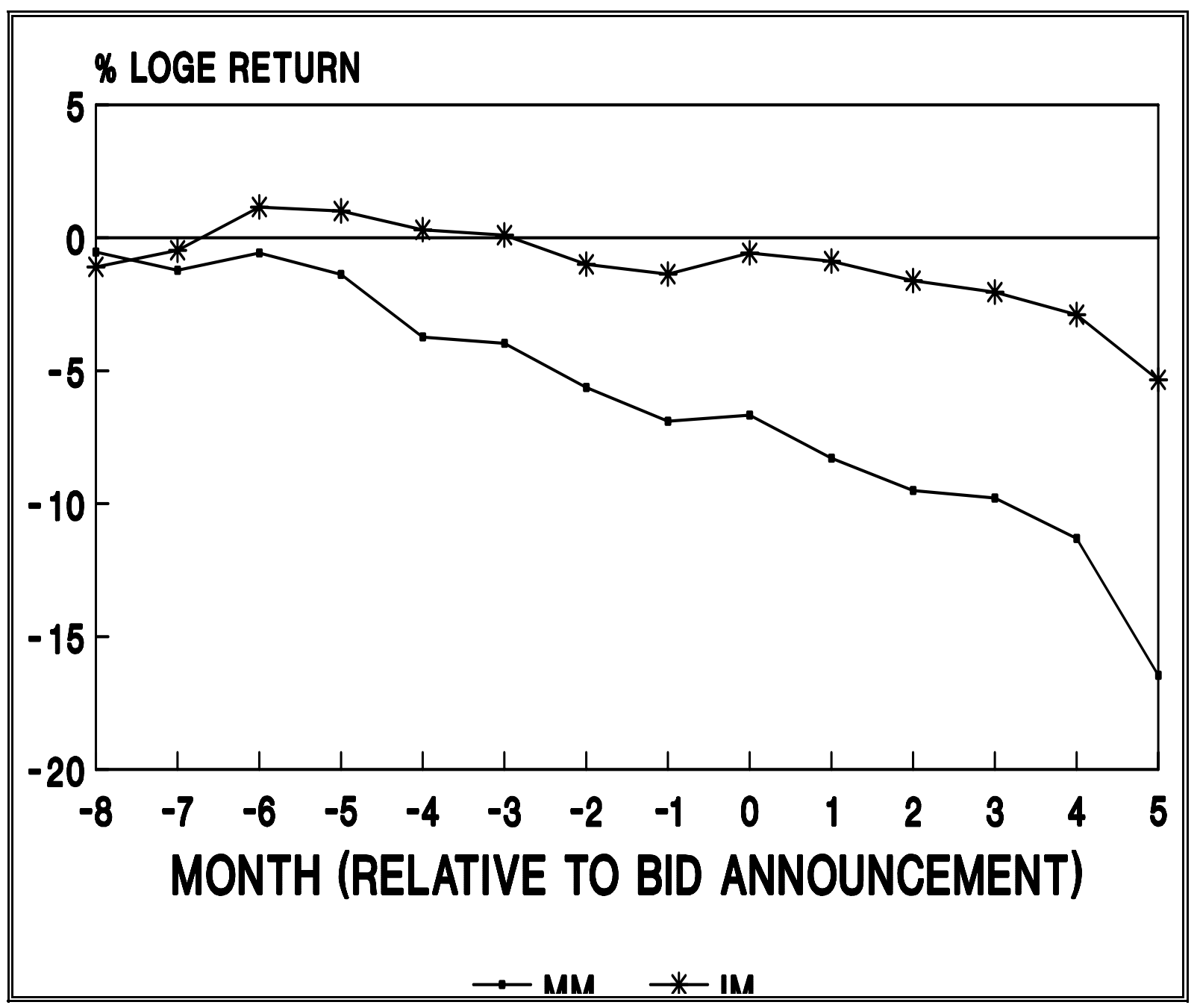


Table 1

Takeover Bids for Listed UK Companies (1986-1991); By Nationality of the Cross-Border Bidding Companies

Of the 208 cross-border takeover bids, 34 were not suitable for analysis (see note 6), leaving a total of 174 for which analysis was attempted. Lack of data reduced the sample further to a total of 71 takeover bids for the index model (IM) and 50 for the market model (MM).

\begin{tabular}{|c|c|c|c|c|}
\hline & $\begin{array}{l}\text { Total number } \\
\text { of bids }\end{array}$ & $\begin{array}{l}\text { Bids for } \\
\text { analysis }\end{array}$ & $\begin{array}{c}\text { Sample } \\
\text { IM }\end{array}$ & $\begin{array}{c}\text { Sample } \\
\text { MM }\end{array}$ \\
\hline Austria & 1 & 1 & 0 & 0 \\
\hline Australia & 14 & 12 & 4 & 1 \\
\hline Belgium & 2 & 1 & 0 & 0 \\
\hline Bermuda & 1 & 1 & 0 & 0 \\
\hline British Virgin Islands & 2 & 2 & 0 & 0 \\
\hline Canada & 5 & 5 & 4 & 4 \\
\hline Cayman Islands & 2 & 2 & 0 & 0 \\
\hline Denmark & 3 & 2 & 1 & 1 \\
\hline Eire & 8 & 7 & 6 & 4 \\
\hline Finland & 3 & 3 & 0 & 0 \\
\hline France & 38 & 24 & 10 & 6 \\
\hline Germany & 9 & 9 & 5 & 4 \\
\hline Hong Kong & 1 & 1 & 0 & 0 \\
\hline Italy & 1 & 1 & 1 & 0 \\
\hline Japan & 6 & 6 & 5 & 1 \\
\hline Liechtenstein & 3 & 3 & 0 & 0 \\
\hline Luxembourg & 4 & 2 & 0 & 0 \\
\hline Malaysia & 2 & 1 & 0 & 0 \\
\hline Netherlands & 8 & 7 & 4 & 4 \\
\hline Norway & 3 & 2 & 1 & 1 \\
\hline New Zealand & 13 & 12 & 3 & 0 \\
\hline Panama & 1 & 1 & 0 & 0 \\
\hline South Africa & 4 & 1 & 0 & 0 \\
\hline Saudi Arabia & 2 & 1 & 0 & 0 \\
\hline Sweden & 14 & 14 & 3 & 3 \\
\hline Switzerland & 15 & 15 & 7 & 5 \\
\hline USA & 43 & 38 & 17 & 16 \\
\hline
\end{tabular}




\begin{tabular}{||l|r|r|r|r||}
\hline TOTAL & 208 & 174 & 71 & 50 \\
\hline
\end{tabular}

Table 2

\section{Market Values of Cross-Border Bidding Companies}

Market values of cross-border bidding companies were measured as the capitalised value of the ordinary shares outstanding 9 months prior to the date of the takeover bid for the UK listed target company. Market values were converted into Sterling using exchange rate at day of measurement.

Source: Datastream.

\begin{tabular}{||l|c||}
\hline Market Value (£ millions) & Number of Bids \\
\hline $0-99$ & 8 \\
\hline $100-199$ & 10 \\
\hline $200-399$ & 5 \\
\hline $400-599$ & 5 \\
\hline $600-799$ & 2 \\
\hline $800-999$ & 23 \\
\hline $1000-4999$ & 7 \\
\hline $5000-9999$ & 4 \\
\hline $10000-14999$ & 1 \\
\hline $15000-19999$ & 71 \\
\hline Total number of observations & $£ 2,374.6$ \\
\hline Mean market value (millions) & $£ 3,544.0$ \\
\hline Standard deviation of mean market value (millions) & \\
\hline \hline
\end{tabular}


Table 3

\section{Sign of the Cumulative Abnormal Returns to Cross-Border Bidding Companies}

Time periods refer to months relative to the month of tbe bid announcement, which is denoted $t=0$. The distribution of the cumulative abnormal returns have been tested using the Sign test, corrected for continuity (see Siegel and Castellan (1988), pp. 80-87). The test is specified as follows:

$$
\mathrm{z} \quad=\quad(2 \mathrm{x} \pm 1-\mathrm{N}) / \sqrt{ } \mathrm{N}
$$

where $\mathrm{x}$ is the number of positive abnormal returns and $\mathrm{N}$ the total number of observations. We use +1 when $\mathrm{x}<\mathrm{N} / 2$ and -1 when $\mathrm{x}>\mathrm{N} / 2$. $\mathrm{z}$ is distributed approximately normally with zero mean and unit variance.

For none of the time periods, with either of the models, were the proportion of positive cumulative abnormal returns significantly different from 0.5 .

\begin{tabular}{|c|c|c|c|c|c|c|c|c|}
\hline & \multicolumn{2}{|c|}{$\begin{array}{c}\text { Pre-Bid Period } \\
(\mathrm{t}-8, \mathrm{t}-2) \\
\end{array}$} & \multicolumn{2}{|c|}{$\begin{array}{l}\text { Bid Period } \\
(\mathrm{t}-1, \mathrm{t}=0)\end{array}$} & \multicolumn{2}{|c|}{$\begin{array}{l}\text { Post-Bid Period } \\
(t+1, t+5)\end{array}$} & \multicolumn{2}{|c|}{$\begin{array}{c}\text { Total Analysis Period } \\
(\mathrm{t}-8, \mathrm{t}+5)\end{array}$} \\
\hline & Positive & Negative & Positive & Negative & Positive & Negative & Positive & Negative \\
\hline IM & $40.8 \%$ & $59.2 \%$ & $50.7 \%$ & $49.3 \%$ & $50.7 \%$ & $49.3 \%$ & $40.8 \%$ & $59.2 \%$ \\
\hline MM & $44.0 \%$ & $56.0 \%$ & $44.0 \%$ & $56.0 \%$ & $40.0 \%$ & $60.0 \%$ & $40.0 \%$ & $60.0 \%$ \\
\hline
\end{tabular}




\section{Table 4}

\section{Percent $\log _{\mathrm{e}}$ Average Abnormal Returns to Cross-Border Bidding Companies}

Average abnormal returns (AR) and cumulative abnormal returns (CAR) to overseas companies making takeover bids for UK listed companies (1986-1991). The AR/CAR has been estimated using the market model (MM) and the index model (IM), specified as follows:

$$
\begin{array}{ll}
\text { MM: } & \log _{\mathrm{e}} R_{\mathrm{i}}=\alpha_{\mathrm{i}}+\beta_{\mathrm{i}} \log _{\mathrm{e}} R_{\mathrm{m}}+\mu_{\mathrm{i}} \\
\text { IM: } & \log _{\mathrm{e}} R_{\mathrm{i}}=\log _{\mathrm{e}} R_{\mathrm{m}}+\mu_{\mathrm{i}}
\end{array}
$$

where $\log _{e}$ is the natural $\log , R_{i}$ is the return on the share, $R_{m}$ the return on the market, $\alpha_{i}$ and $\beta_{i}$ regression coefficients, and $\mu_{i}$ the estimated abnormal return during time period $\mathrm{i}$. Time periods refer to months relative to the month of the bid announcement, which is denoted $\mathrm{t}=0$.

\begin{tabular}{||l|c|c||}
\hline Period & Index Model & Market Model \\
\hline$t-8$ & -1.10 & -0.54 \\
\hline$t-7$ & 0.63 & -0.68 \\
\hline$t-6$ & $1.63^{* *}$ & 0.65 \\
\hline$t-4$ & -0.15 & -0.81 \\
\hline$t-3$ & -0.71 & $-2.36^{*}$ \\
\hline$t-2$ & -0.20 & -0.24 \\
\hline$t-1$ & -1.11 & -1.67 \\
\hline$t=0$ & -0.36 & -1.26 \\
\hline$t+1$ & 0.80 & 0.23 \\
\hline$t+2$ & -0.32 & -1.62 \\
\hline$t+3$ & -0.74 & -1.22 \\
\hline$t+4$ & -0.42 & -0.28 \\
\hline$t+5$ & -0.84 & -1.53 \\
\hline
\end{tabular}

\begin{tabular}{|c|c|c|c|}
\hline Pre-bid period & $(\mathrm{t}-8, \mathrm{t}-2)$ & -1.00 & $-5.63^{\star}$ \\
\hline Bid period & $(\mathrm{t}-1, \mathrm{t}=0)$ & 0.44 & -1.03 \\
\hline Post-bid period & $(t+1, t+5)$ & $-4.77^{* \star}$ & $-9.79^{\star \star \star}$ \\
\hline \multicolumn{2}{|c|}{ Total analysis period $(t-8, t+5)$} & $-5.34^{*}$ & $-16.46^{\star \star \star}$ \\
\hline
\end{tabular}

Percent $\log _{\mathrm{e}}$ Average Cumulative Abnormal Returns

${ }^{*},{ }^{* *}$, and ${ }^{* * *}$ indicates that the null hypothesis of abnormal return/cumulative abnormal return equal to zero has been rejected at the 10, 5 or 1 percent level of significance respectively. Following Strong (1992) and Kumar, Sen and Shome (1992), the Patell Standardised Residual (PSR) Test (Patell (1976)) has been applied for the MM. The simple t-test (Strong (1992), pp. 544-545) has been applied for the IM. 
Table 5

Comparative Analysis of Average Market Model Parameters

\begin{tabular}{||l|c|c||}
\hline & Alpha & Beta \\
\hline Present study - Overseas bidders & 0.009 & 0.788 \\
\hline Franks and Harris (1989) - UK bidders & 0.010 & 0.92 \\
\hline Limmack (1991) - UK bidders & 0.006 & 0.86 \\
\hline Connell and Conn (1993) - UK bidders & 0.003 & 1.061 \\
\hline Connell and Conn (1993) - US bidders & 0.001 & 0.806 \\
\hline
\end{tabular}


Table 6

\section{Percent $\log _{\mathrm{e}}$ Cumulative Abnormal Returns over Analysis Period $(t-8, t+5)$ to American versus European (Non-UK) Bidders}

"American bidders" includes bidding companies based in US and Canada, while "European (non-UK) bidders" comprises bidding companies based in Denmark, Eire, France, Germany, Italy, Netherlands, Norway, Sweden, and Switzerland. A full breakdown of the nationality of the cross-border bidders is provided in Table 1.

\begin{tabular}{||l|c|c|}
\hline & Index Model & Market Model \\
\hline American bidders & $\begin{array}{c}-4.88 \% \\
(-0.99)\end{array}$ & $\begin{array}{c}-5.13 \% \\
(-0.99)\end{array}$ \\
\hline European (non-UK) bidders & $\begin{array}{c}-9.82 \%^{*} \\
(-1.87)\end{array}$ & $\begin{array}{c}-26.81 \%^{* * *} \\
(-2.90)\end{array}$ \\
\hline t-test for difference of & 0.69 & $2.04^{* *}$ \\
means & & \\
\hline
\end{tabular}

$t$-statistics in parentheses. ${ }^{*},{ }^{\star \star}$, and ${ }^{\star \star \star}$ indicates value statistically significant at the 10,5 or 1 percent level of significance respectively. 
Table 7

\section{Cross-Sectional Analysis of Pre-Bid Period (t-8, t-2) Percent $\log _{\mathrm{e}}$ Cumulative Abnormal Returns}

The following table contains regression output from analysis of the influence of various bid characteristics on the average CAR to overseas bidding companies. Various specifications were applied, such as (number 5) involving all the explanatory variables, specified as follows:

$\mathrm{CAR}_{\mathrm{i}}=$ Constant $+\beta_{1}$ Outcome $+\beta_{2}$ Competitive $+\beta_{3}$ Revised $+\beta_{4}$ Pay $+\beta_{5}$ Rel Size $+\beta_{6}$ Size $+\varepsilon_{\mathrm{i}}$

Outcome is a dummy variable taking the value of 0 if the bid was successful (in that the bidding company obtained control over the target company) and 1 if the offer failed, Competitive is a dummy variable taking the value of 0 if there was a single bidder and the value 1 if more than one company bid for the target (competitive bid), Revised is a dummy variable taking the value 0 if the offer was not revised and the value 1 if the terms of the offer were revised (price offered increased), Pay is a dummy variable taking the value of 0 if there was not a full cash alternative and the value 1 if the offer included a full cash alternative, Rel Size measures the pre-bid market value of the target divided by the pre-bid market value of the bidder, Size is the natural log of the pre-bid market value of the bidding company, and $\varepsilon$ is an error term.

\begin{tabular}{|c|c|c|c|c|c|c|c|c|c|c|}
\hline & \multicolumn{5}{|c|}{ Index Model } & \multicolumn{5}{|c|}{ Market Model } \\
\hline & 1 & 2 & 3 & 4 & 5 & 1 & 2 & 3 & 4 & 5 \\
\hline Constant & $\begin{array}{l}-0.006 \\
(-0.25) \\
\end{array}$ & $\begin{array}{l}-0.014 \\
(-0.14) \\
\end{array}$ & $\begin{array}{l}-0.013 \\
(-0.14) \\
\end{array}$ & $\begin{array}{c}-0.292^{* * *} \\
(-2.79) \\
\end{array}$ & $\begin{array}{c}-0.384^{* *} \\
(-2.18) \\
\end{array}$ & $\begin{array}{l}-0.048 \\
(-1.31) \\
\end{array}$ & $\begin{array}{l}-0.093 \\
(-0.58) \\
\end{array}$ & $\begin{array}{l}-0.089 \\
(-0.59) \\
\end{array}$ & $\begin{array}{c}-0.365^{* *} \\
(-2.33) \\
\end{array}$ & $\begin{array}{c}-0.476^{* *} \\
(-2.03) \\
\end{array}$ \\
\hline Outcome & $\begin{array}{l}0.021 \\
(0.37) \\
\end{array}$ & $\begin{array}{l}0.002 \\
(0.04) \\
\end{array}$ & & & $\begin{array}{l}0.013 \\
(0.19) \\
\end{array}$ & $\begin{array}{l}0.084 \\
(1.00) \\
\end{array}$ & $\begin{array}{l}0.007 \\
(0.09) \\
\end{array}$ & & & $\begin{array}{l}0.005 \\
(0.05) \\
\end{array}$ \\
\hline Competitive & $\begin{array}{l}-0.052 \\
(-0.89) \\
\end{array}$ & & $\begin{array}{l}-0.039 \\
(-0.79) \\
\end{array}$ & & $\begin{array}{c}-0.138^{* *} \\
(-2.05) \\
\end{array}$ & $\begin{array}{l}-0.171^{* *} \\
(-2.04) \\
\end{array}$ & & $\begin{array}{l}-0.099 \\
(-1.43) \\
\end{array}$ & & $\begin{array}{c}-0.219^{\star *} \\
(-2.09) \\
\end{array}$ \\
\hline Revised & $\begin{array}{l}0.021 \\
(0.30)\end{array}$ & & & & $\begin{array}{l}0.074 \\
(1.01)\end{array}$ & $\begin{array}{l}0.137 \\
(1.40)\end{array}$ & & & & $\begin{array}{l}0.172 \\
(1.57)\end{array}$ \\
\hline Pay & & $\begin{array}{l}0.004 \\
(0.03)\end{array}$ & $\begin{array}{l}0.011 \\
(0.11)\end{array}$ & & $\begin{array}{l}0.107 \\
(0.62)\end{array}$ & & $\begin{array}{l}0.037 \\
(0.23)\end{array}$ & $\begin{array}{l}0.061 \\
(0.39)\end{array}$ & & $\begin{array}{l}0.182 \\
(0.79)\end{array}$ \\
\hline Rel Size & & & & $\begin{array}{c}0.0007^{* *} \\
(2.01) \\
\end{array}$ & $\begin{array}{c}0.0008^{*} \\
(1.98) \\
\end{array}$ & & & & $\begin{array}{c}0.0010^{*} \\
(2.01)\end{array}$ & $\begin{array}{c}0.0011^{*} \\
(2.00)\end{array}$ \\
\hline Size & & & & $\begin{array}{l}0.041^{\text {**t }} \\
(2.72) \\
\end{array}$ & $\begin{array}{l}0.041^{* *} \\
(2.65)\end{array}$ & & & & $\begin{array}{l}0.043^{*} \\
(1.96) \\
\end{array}$ & $\begin{array}{l}0.037 \\
(1.66) \\
\end{array}$ \\
\hline Obs & 71 & 71 & 71 & 55 & 55 & 50 & 50 & 50 & 39 & 39 \\
\hline Adj $R^{2}$ & $0.0 \%$ & $0.0 \%$ & $0.0 \%$ & $9.3 \%$ & $10.9 \%$ & $2.8 \%$ & $0.0 \%$ & $0.2 \%$ & $6.7 \%$ & $12.6 \%$ \\
\hline $\begin{array}{l}\text { F value } \\
\text { (p-value) }\end{array}$ & $\begin{array}{c}0.26 \\
(0.851)\end{array}$ & $\begin{array}{c}0.00 \\
(0.999)\end{array}$ & $\begin{array}{c}0.31 \\
(0.734)\end{array}$ & $\begin{array}{c}3.76 \\
(0.030)\end{array}$ & $\begin{array}{c}2.10^{*} \\
(0.070)\end{array}$ & $\begin{array}{c}1.46 \\
(0.237)\end{array}$ & $\begin{array}{c}0.03 \\
(0.973)\end{array}$ & $\begin{array}{c}1.05 \\
(0.358)\end{array}$ & $\begin{array}{c}2.36 \\
(0.109)\end{array}$ & $\begin{array}{c}1.91 \\
(0.109)\end{array}$ \\
\hline
\end{tabular}

$t$-statistics in parentheses. ${ }^{*},{ }^{\star *}$, and ${ }^{* \star *}$ indicates value statistically significant at the 10,5 or 1 percent level of significance respectively. 
Table 8

\section{Cross-Sectional Analysis of Bid Period $(t-1, t=0)$ Percent $\log _{\mathrm{e}}$ Cumulative Abnormal Returns}

Variables as defined in table 7.

\begin{tabular}{|c|c|c|c|c|c|c|c|c|c|c|}
\hline & \multicolumn{5}{|c|}{ Index Model } & \multicolumn{5}{|c|}{ Market Model } \\
\hline & 1 & 2 & 3 & 4 & 5 & 1 & 2 & 3 & 4 & 5 \\
\hline Constant & $\begin{array}{l}-0.009 \\
(-0.64) \\
\end{array}$ & $\begin{array}{l}-0.071 \\
(-1.29) \\
\end{array}$ & $\begin{array}{l}-0.055 \\
(-1.01) \\
\end{array}$ & $\begin{array}{l}-0.050 \\
(-0.78) \\
\end{array}$ & $\begin{array}{l}-0.196^{*} \\
(-1.82) \\
\end{array}$ & $\begin{array}{l}-0.020 \\
(-1.14) \\
\end{array}$ & $\begin{array}{l}-0.065 \\
(-0.90) \\
\end{array}$ & $\begin{array}{l}-0.046 \\
(-0.64) \\
\end{array}$ & $\begin{array}{l}-0.137^{*} \\
(-1.94) \\
\end{array}$ & $\begin{array}{c}-0.262^{* *} \\
(-2.35) \\
\end{array}$ \\
\hline Outcome & $\begin{array}{l}0.035 \\
(1.08) \\
\end{array}$ & $\begin{array}{l}0.049 \\
(1.63) \\
\end{array}$ & & & $\begin{array}{l}0.035 \\
(0.84) \\
\end{array}$ & $\begin{array}{l}0.048 \\
(1.21) \\
\end{array}$ & $\begin{array}{l}0.039 \\
(1.09) \\
\end{array}$ & & & $\begin{array}{l}0.037 \\
(0.70) \\
\end{array}$ \\
\hline Competitive & $\begin{array}{l}0.029 \\
(0.86) \\
\end{array}$ & & $\begin{array}{l}0.041 \\
(1.44) \\
\end{array}$ & & $\begin{array}{l}0.033 \\
(0.80) \\
\end{array}$ & $\begin{array}{l}-0.025 \\
(-0.64) \\
\end{array}$ & & $\begin{array}{l}0.005 \\
(0.15) \\
\end{array}$ & & $\begin{array}{l}-0.025 \\
(-0.50) \\
\end{array}$ \\
\hline Revised & $\begin{array}{l}0.012 \\
(0.30) \\
\end{array}$ & & & & $\begin{array}{l}0.004 \\
(0.08) \\
\end{array}$ & $\begin{array}{l}-0.046 \\
(0.98) \\
\end{array}$ & & & & $\begin{array}{l}0.039 \\
(0.76) \\
\end{array}$ \\
\hline Pay & & $\begin{array}{l}0.070 \\
(1.26) \\
\end{array}$ & $\begin{array}{l}0.054 \\
(0.95) \\
\end{array}$ & & $\begin{array}{l}0.165 \\
(1.57) \\
\end{array}$ & & $\begin{array}{l}0.049 \\
(0.67) \\
\end{array}$ & $\begin{array}{l}0.035 \\
(0.48) \\
\end{array}$ & & $\begin{array}{l}0.153 \\
(1.40) \\
\end{array}$ \\
\hline Rel Size & & & & $\begin{array}{c}0.0002 \\
(1.12) \\
\end{array}$ & $\begin{array}{c}0.0004 \\
(1.57) \\
\end{array}$ & & & & $\begin{array}{c}0.0005^{* \star} \\
(2.12) \\
\end{array}$ & $\begin{array}{c}0.0006^{* *} \\
(2.21) \\
\end{array}$ \\
\hline Size & & & & $\begin{array}{l}0.010 \\
(1.05) \\
\end{array}$ & $\begin{array}{l}0.006 \\
(0.58) \\
\end{array}$ & & & & $\begin{array}{l}0.019^{*} \\
(1.89) \\
\end{array}$ & $\begin{array}{l}0.015 \\
(1.36) \\
\end{array}$ \\
\hline Obs & 71 & 71 & 71 & 55 & 55 & 50 & 50 & 50 & 39 & 39 \\
\hline Adj $R^{2}$ & $0.7 \%$ & $2.6 \%$ & $1.8 \%$ & $0.0 \%$ & $1.2 \%$ & $0.0 \%$ & $0.0 \%$ & $0.0 \%$ & $7.1 \%$ & $4.5 \%$ \\
\hline $\begin{array}{l}\text { F value } \\
\text { (p-value) }\end{array}$ & $\begin{array}{c}1.17 \\
(0.326)\end{array}$ & $\begin{array}{c}1.94 \\
(0.151)\end{array}$ & $\begin{array}{c}1.64 \\
(0.201)\end{array}$ & $\begin{array}{c}0.72 \\
(0.491)\end{array}$ & $\begin{array}{c}1.11 \\
(0.372)\end{array}$ & $\begin{array}{c}0.66 \\
(0.579)\end{array}$ & $\begin{array}{c}0.72 \\
(0.491)\end{array}$ & $\begin{array}{c}0.14 \\
(0.870)\end{array}$ & $\begin{array}{c}2.45 \\
(0.101)\end{array}$ & $\begin{array}{c}1.3 \\
(0.286)\end{array}$ \\
\hline
\end{tabular}

$t$-statistics in parentheses. ${ }^{*}, * *$, and ${ }^{* * *}$ indicates value statistically significant at the 10,5 or 1 percent level of significance respectively. 
Table 9

Cross-Sectional Analysis of Total Analysis Period (t-8, $t+5)$ Percent $\log _{\mathrm{e}}$ Cumulative Abnormal Returns

Variables as defined in table 7.

\begin{tabular}{|c|c|c|c|c|c|c|c|c|c|c|}
\hline & \multicolumn{5}{|c|}{ Index Model } & \multicolumn{5}{|c|}{ Market Model } \\
\hline & 1 & 2 & 3 & 4 & 5 & 1 & 2 & 3 & 4 & 5 \\
\hline Constant & $\begin{array}{l}-0.036 \\
(-0.89) \\
\end{array}$ & $\begin{array}{l}-0.239 \\
(-1.43) \\
\end{array}$ & $\begin{array}{l}-0.257 \\
(-1.58) \\
\end{array}$ & $\begin{array}{c}-0.619^{* * \star} \\
(-3.50) \\
\end{array}$ & $\begin{array}{c}-0.881^{* * *} \\
(-2.98) \\
\end{array}$ & $\begin{array}{l}-0.137^{\star} \\
(-1.96) \\
\end{array}$ & $\begin{array}{l}-0.326 \\
(-1.06) \\
\end{array}$ & $\begin{array}{l}-0.347 \\
(-1.20) \\
\end{array}$ & $\begin{array}{c}-0.888^{\star * \star} \\
(-2.94) \\
\end{array}$ & $\begin{array}{c}-1.131^{* *} \\
(-2.51) \\
\end{array}$ \\
\hline Outcome & $\begin{array}{l}-0.031 \\
(-0.32)\end{array}$ & $\begin{array}{c}-0.054 \\
(-0.60)\end{array}$ & & & $\begin{array}{l}-0.036 \\
(-0.31)\end{array}$ & $\begin{array}{l}0.102 \\
(0.64)\end{array}$ & $\begin{array}{l}-0.043 \\
(-0.29)\end{array}$ & & & $\begin{array}{l}0.007 \\
(0.03)\end{array}$ \\
\hline Competitive & $\begin{array}{l}-0.086 \\
(-0.86) \\
\end{array}$ & & $\begin{array}{l}-0.096 \\
(-1.14) \\
\end{array}$ & & $\begin{array}{l}-0.208^{*} \\
(-1.84) \\
\end{array}$ & $\begin{array}{c}-0.339^{* *} \\
(-2.10) \\
\end{array}$ & & $\begin{array}{l}-0.221 \\
(-1.67) \\
\end{array}$ & & $\begin{array}{c}-0.421^{\text {** }} \\
(-2.09) \\
\end{array}$ \\
\hline Revised & $\begin{array}{l}0.041 \\
(0.34)\end{array}$ & & & & $\begin{array}{l}0.099 \\
(0.81)\end{array}$ & $\begin{array}{l}0.290 \\
(1.54)\end{array}$ & & & & $\begin{array}{l}0.337 \\
(1.59)\end{array}$ \\
\hline Pay & & $\begin{array}{l}0.203 \\
(1.21) \\
\end{array}$ & $\begin{array}{l}0.232 \\
(1.39)\end{array}$ & & $\begin{array}{l}0.325 \\
(1.12) \\
\end{array}$ & & $\begin{array}{l}0.177 \\
(0.58)\end{array}$ & $\begin{array}{l}0.250 \\
(0.84)\end{array}$ & & $\begin{array}{l}0.387 \\
(0.87)\end{array}$ \\
\hline Rel Size & & & & $\begin{array}{c}0.0011^{*} \\
(1.80) \\
\end{array}$ & $\begin{array}{c}0.0015^{* *} \\
(2.17) \\
\end{array}$ & & & & $\begin{array}{c}0.0020^{* *} \\
(2.05) \\
\end{array}$ & $\begin{array}{c}0.0023^{\text {*t }} \\
(2.08) \\
\end{array}$ \\
\hline Size & & & & $\begin{array}{l}0.083^{* * *} \\
(3.28)\end{array}$ & $\begin{array}{l}0.079^{\text {tht }} \\
(3.06)\end{array}$ & & & & $\begin{array}{l}0.102^{* *} \\
(2.38)\end{array}$ & $\begin{array}{l}0.089^{* *} \\
(2.05)\end{array}$ \\
\hline Obs & 71 & 71 & 71 & 55 & 55 & 50 & 50 & 50 & 39 & 39 \\
\hline $\operatorname{Adj~} R^{2}$ & $0.0 \%$ & $0.0 \%$ & $1.3 \%$ & $14.1 \%$ & $16.7 \%$ & $3.8 \%$ & $0.0 \%$ & $2.4 \%$ & $9.6 \%$ & $15.7 \%$ \\
\hline $\begin{array}{l}\text { F value } \\
\text { (p-value) }\end{array}$ & $\begin{array}{c}0.41 \\
(0.745)\end{array}$ & $\begin{array}{c}0.99 \\
(0.378)\end{array}$ & $\begin{array}{c}1.47 \\
(0.238)\end{array}$ & $\begin{array}{c}5.44 \\
(0.007)\end{array}$ & $\begin{array}{c}2.81 \\
(0.020)\end{array}$ & $\begin{array}{c}1.65 \\
(0.191)\end{array}$ & $\begin{array}{c}0.24 \\
(0.789)\end{array}$ & $\begin{array}{c}1.60 \\
(0.213)\end{array}$ & $\begin{array}{c}3.01 \\
(0.062)\end{array}$ & $\begin{array}{c}2.18 \\
(0.072)\end{array}$ \\
\hline
\end{tabular}

$t$-statistics in parentheses. ${ }^{*}, * \star$, and ${ }^{* * *}$ indicates value statistically significant at the 10,5 or 1 percent level of significance respectively. 


\section{NOTES}

i. These models were (i) the market model, (ii) a model based on adjusted betas, and (iii) the index model.

ii. Conn and Connell used various forms of the market model; they used both pre-, pooled-, and postevent alphas and betas, as well as a Domestic and an International version of the market model. The $2.5 \%$ abnormal loss reported here was calculated using the domestic market model with alpha and beta parameters estimated over the period from 36 to 7 months prior to the bid announcement.

iii. Biswas analysed the returns to 125 bidding companies from 12 countries and 81 target companies from 11 countries. She did not, however, comment on whether there were any national variations, but rather treated all the cross-border bidding companies as a homogenous group (and likewise with the cross-border target companies).

iv. For some companies the required market capitalisation information was not available from the LBS RMS. In these circumstances, attempts were made to obtain the information from Datastream International. Due to some of the target companies only being traded in the OTC market, for a few firms the market capitalisation was not available from either the LBS RMS or Datastream.

v. Fatemi and Furtado (1988) also faced a problem of incomplete information. While it was known that 93 of the companies. However, for the 24 companies deemed to have no overseas operations, the authors could confirm the lack of overseas subsidiaries for only 2 . Thus, for the remaining 22 companies there was a lack of information, and these companies were simply assumed not to have overseas operations.

vi. Firstly, five offers have been excluded from the analysis due to these being partial bids. The Takeover Code (The Panel on Takeovers and Mergers (1990)) stipulates that normally offers have to be made for all outstanding shares. Special dispensation is required prior to the announcement of a partial takeover bid. Such bids are therefore unusual. Offers for British investment trusts (9 bids) have also been excluded. Such companies are generally valued as a percentage of their net asset value, and the offer value fluctuates in line with the market value of the assets of the target company. The last major category of bids excluded from the analysis, is offers for British water companies (13 bids). As explained by The Department of Trade and Industry (1991), "There are special arrangements for water company mergers under the Water Act 1989. A merger must be referred to the Monopolies and Mergers Commission if the water-related assets of the acquiring company and the acquired company are each more than $£ 30 \mathrm{~m} "$. (p. 5). Two bids were rejected as they were joint bids between two foreign companies. A further five bids were rejected for other reasons, mainly due to incomplete information from Acquisitions Monthly.

vii. Thirteen of the foreign bidding companies attempted to acquire two or more listed UK companies during the period from 1986 to 1991 (the 174 cross-border takeover bids into the UK were made by a total of 156 different overseas entities). When analysing the abnormal return to shareholders from a takeover bid for a "frequent bidder", there is a possible danger of the Market Model parameters and/or the abnormal return estimates being 'contaminated' by the effect of a previous takeover. One way to overcome this potential problem, is to exclude from the analysis takeover bids by companies which made (or indeed, received) other takeover bids during the analysis period. For two distinct reasons, such an approach has not been adopted here.

Firstly, there is a possibility that companies which attempt a second merger are the ones which considered their first acquisition to be a financial success, while the ones who do not go on to make a second takeover bid are the ones who regret having made the first acquisition. In his study of mergers and acquisitions in the German market, Bühner (1991) established that "Firms that have frequent experience of mergers tend to gain from their mergers" (p. 513), while infrequent bidders tended to experience large negative cumulative abnormal returns. Thus, excluding frequent bidders from the analysis may lead to an exclusion of "successful" bidders, thus introducing a negative bias into the analysis.

Secondly, there is a problem of data availability. If frequent bidders were to be excluded from the analysis, it would be necessary to know of all takeover bids (not only for listed UK companies, but also for private UK companies as well as for listed and private foreign companies) made (or received) during the 74 month period from 68 months prior to the month of the takeover bid to 5 months after the bid. It has, unfortunately, not been possible to obtain this information.

viii. In this study, the return to bidders has been compared to the return on the stock market index (price change and average dividend yield) in their home countries. Conn and Connell (1990) applied both a domestic market model (DMM) and an international market model (IMM). They concluded, 
however, that "...there is no compelling reason to incur the extra research costs associated with the more complex IMM". (p. 708). Roll (1977) argued that the stock market index is misspecified as a proxy for the return on the market. However, as argued by Schipper and Thompson (1983), "...whatever bias result from misspecification should be contained in the entire matrix of residuals, both in and out of the event periods. Unusual residual behavior in the event periods, relative to the residuals in the non-event periods, is suggestive of something more than model misspecification". (p. 96).

ix. $\quad$ MM has only been applied if at least 30 observations were available during the parameter estimation period.

x. For example, Franks, Broyles and Hecht (1977) found that share prices of target companies started rising significantly 3 months prior to the announcement of the takeover bid. Hannigan (1988) argued that "... take-overs provide prime insider dealing opportunities...", and used an Acquisitions Monthly survey (published March 1986) to support her argument: "Acquisitions Monthly ... found that of 1200 mergers studied, the price of the target rose by $54 \%$ during the 6 months before the bid, $39 \%$ during the month before and $25 \%$ on the day before". (p. 18). While the Acquisitions Monthly survey referred to target rather than bidding companies, it is plausible that if investors can predict who will become takeover targets up to six month prior to the bid announcement, they may also be able to identify the bidding companies.

xi. Companies have only been included in the analysis if return data was available for the whole analysis period from 8 months prior to the month of the bid announcement, to 5 months after the month in which the takeover offer was made.

xii. Sea Containers, a Bermuda based company, has been included in the analysis, but has been classified as USA based, as that is where the company has its shares listed.

xiii.

Franks and Harris found a large difference in the (post-announcement) cumulative abnormal returns dependent on the control model applied. The CAR (or TAR in their terminology) over the 24 months following the bid announcement was positive (and significant) using the index model and CAPM, and significantly negative when applying the market model (p. 245).

xiv. Fowler, Rorke and Jog evaluated (i) the Scholes and Williams technique (1977), (ii) the Scholes and Williams Extended (as developed by Fowler and Rorke (1979) (described in Fowler, Rorke and Jog 1980), (iii) the Scholes and Williams with Jafnike, and lastly (iv) the Dimson technique (1979).

XV.

The analysis was also performed using the Capital Asset Pricing Model (CAPM). The results (not reported here) lies somewhere between those for the Market Model and the Index Model. 